\title{
Reviewer Acknowledgements for Global Journal of Health Science, Vol. 9, No. 10
}

Global Journal of Health Science wishes to acknowledge the following individuals for their assistance with peer review of manuscripts for this issue. Their help and contributions in maintaining the quality of the journal are greatly appreciated.

Global Journal of Health Science is recruiting reviewers for the journal. If you are interested in becoming a reviewer, we welcome you to join us. Please find the application form and details at http://recruitment.ccsenet.org and e-mail the completed application form to gjhs@ccsenet.org.

\section{Reviewers for Volume 9, Number 10}

Abin Varghese, Bhopal Memorial Hospital and Research Centre, India

Abiodun Adeniran, University of Ilorin, Nigeria

Ama Pokuaa Fenny,University of Ghana, Ghana

Angus N. Oli, Nnamdi Azikiwe University, Nigeria

Arpad Kovacs, University of Kaposvar, University of Pecs, Hungary

Ayesha Johnson, University of South Florida, United States

Carlos Aceves-Gonzalez, Ergonomic Research Centre of University of Guadalajara, Mexico

Chung-Yu Chen, Kaohsiung Medical University Hospital, Taiwan, Province of China

Clauden Louis, University of Rochester Medical Center, United States

Darampal Dambhare, Mahatma Gandhi Institute of Medical Sciences, India

Dongxu Fu, University of Virginia, United States

Evanthia Sakellari, Technological Educational Institute of Athens, Greece

Francisco Rodenas Rigla, University of Valencia, Spain

Gabriele Messina, University of Siena, Italy

Gaia de Campora, Italian Association of Psychology, Italy

Georgann Valerie Weissman, Capella University, United States

Helen Lida Smits, Retired; serve as Faculty for the Institute of Healthcare Improvement in Boston, United States

Hui Peng, Yijishan Hospital of Wannan Medical College, China

Hülya Yardimci, Ankara University, Turkey

Jan Chrastina, Palacký University, Czech Republic

Jose Manuel Hernandez-Padilla, Middlesex University, United Kingdom

Jose R. Cordon, Universidad de Cadiz (Spain), Spanish Goverment, Spain

Keun-Yeong Jeong, OncoMetplus Pharmaceuticals, Korea, Republic of

Kinley Wangdi, Australian National University, Australia

Leena Kunnath Chacko, Father Muller College of Nursing, India

Loray Daws, British Columbia Masterson Institute, Canada

Madhu Ouseph, Brown University, United States

Pi-Ming Yeh, Missouri Western State University, United States

Raphaële GIRARD, Hospices Civils de Lyon, France

Raymond Compton Jagessar, University of Guyana, Guyana

Thammanard Charernboon, Thammasat University, Thailand

Valery Piacherski, Mogilev Regional Hospital, Anesthesiology and Intensive Care of the Mogilev Executive Committee, Belarus 